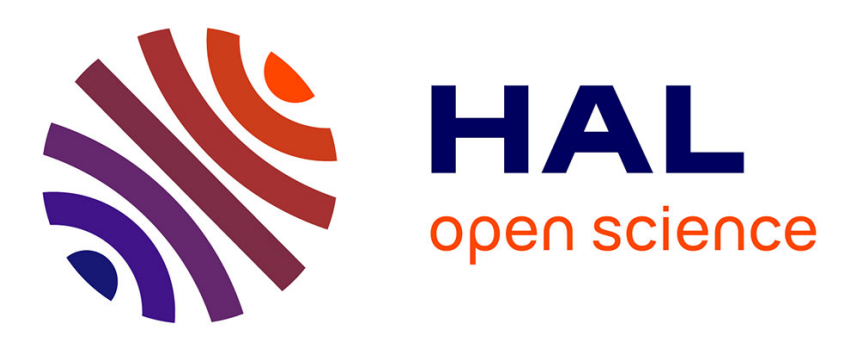

\title{
A Multi-Agent Based System with Big Data Processing for Enhanced Supply Chain Agility
}

Mihalis Giannakis, Michalis Louis

\section{To cite this version:}

Mihalis Giannakis, Michalis Louis. A Multi-Agent Based System with Big Data Processing for Enhanced Supply Chain Agility. Journal of Enterprise Information Management, 2016, 29 (5), 10.1108/JEIM-06-2015-0050 . hal-01353916

\section{HAL Id: hal-01353916 https://hal-audencia.archives-ouvertes.fr/hal-01353916}

Submitted on 16 Aug 2016

HAL is a multi-disciplinary open access archive for the deposit and dissemination of scientific research documents, whether they are published or not. The documents may come from teaching and research institutions in France or abroad, or from public or private research centers.
L'archive ouverte pluridisciplinaire HAL, est destinée au dépôt et à la diffusion de documents scientifiques de niveau recherche, publiés ou non, émanant des établissements d'enseignement et de recherche français ou étrangers, des laboratoires publics ou privés. 


\title{
A Multi-Agent Based System with Big Data Processing for Enhanced Supply Chain Agility
}

\author{
Mihalis Giannakis, Audencia Business School, Nantes, France \\ Michalis Louis, University College Dublin, Ireland
}

\begin{abstract}
Purpose: Decision support systems have become an indispensable tool for managing complex supply chains. This paper develops a multi-agent based supply chain management system that incorporates big data analytics that can exert autonomous corrective control actions. The effects of the system on supply chain agility are explored.

Design/methodology/approach: For the development of the architecture of the system, a sequential approach is adopted. First three fundamental dimensions of supply chain agility are identified responsiveness, flexibility and speed. Then the organisational design of the system is developed. The roles for each of the agents within the framework are defined and the interactions among these agents are modelled.

Findings: Applications of the model are discussed, to show how the proposed model can potentially provide enhanced levels in each of the dimensions of supply chain agility.

Research limitations/implications: The study shows how the multi-agent systems can assist to overcome the trade-off between supply chain agility and complexity of global supply chains. It also opens up a new research agenda for incorporation of big data and semantic web applications for the design of supply chain information systems.

Practical implications: The proposed information system provides integrated capabilities for production, supply chain event and disruption risk management under a collaborative basis

Originality/value. A novel aspect in the design of multi-agent systems is introduced for interorganisational processes, which incorporates semantic web information and a big data ontology in the agent society.
\end{abstract}

Keywords: Multi Agent Systems, Supply Chain Management, Big Data, Agility

Glossary: DSS - Decision Support Systems; ERP - Enterprise Resource Planning; IT - Information Technology; LSP - Logistic Service Providers; $M A S$ - Multi Agent Based Systems; $S C M$ - Supply Chain Management.

\section{Introduction}

The growing need for customized products and services in many industries and the unprecedented levels of outsourcing have made modern global supply chains more complex than ever before. The increased level of supply chain complexity elevates the degree of uncertainty and risks that companies are faced with (Manuj and Mentzer, 2008). In order to reduce the level of uncertainty, organisations can design and manage agile supply chains so that they can responsively fulfil demand (Braunscheidel and Suresh, 2009). Agility is recognised as one of the most prominent capabilities of modern SCM (Christopher and Towill, 2001; Agarwal et al., 2008). It is conceptualized as the ability of firms to better deal with unexpected events, to overcome unforeseen situations of business environment as to take benefits and opportunities of changes (Swafford et al., 2008).

A prerequisite for the development of agile supply chains is the development of a synergistic ethos of cooperation amongst supply chain partners and establishment of mutual trust (Christopher and 
Towill, 2000). Business relationships that are based on (a) asymmetric distribution of power where decisions are centralised to powerful organisations, and (b) on an opportunistic dogma of arm's length relationships, should be transformed to collaborative partnerships where decision making is decentralised (Christopher and Lee, 2004; Gligor and Holocomb, 2012). Two factors play a deterministic role in this metamorphosis; human and information technology. Gattorna (2006) underlines that both factors have an equal role (45\%) for the achievement of supply chain collaboration, attributing the rest $10 \%$ to the tangible assets.

Conventional systems have not provided sustainable solutions for agile supply chains. Their design ideology does not meet the high level of decentralised control that is required for agility (Karwowski et al., 2007). They lack real-time adaptability and focus predominately on dyadic contexts of collaboration (Akkermans et al., 2003). They are characterised by inflexibility in terms of reconfiguration of the supply chains, high development and maintenance costs, and limited computational capacity to manage high level of complexity (Mayer-Schönberger and Kenneth, 2013).

The use of multi-agent modelling can be an alternative decision making tool for collaboration within supply chains. In computer science, an agent is defined as a software entity, which is autonomous to accomplish its design objectives, considered as a part of an overall objective, through the axiom of communication and coordination with other agents. Through this paradigm of software architecture, supply chains processes can be viewed as being composed of several autonomous decision making entities (agents). Each agent is responsible for specific activities and performing different roles, interacting and cooperating with other agents to solve problems beyond their individual expertise in order to achieve higher performance for the entire system (Stone and Veloso, 2000).

In this paper, we develop the architecture of a multi-agent based supply chain system and show how agent based systems can promote supply chain agility. The system draws on principles and theories of SCM, agent-based simulation and computer science and supports the fulfilment of production, supply chain event and disruption risk management. The proposed architecture introduces a novel aspect in the design of MASs that is not found in previous works; the incorporation of semantic web services and big data in the agent society. We show with illustrative case scenarios, how the proposed MAS can enhance performance in fundamental dimensions of supply chain agility.

The remainder of the paper proceeds as follows. In the second section, salient concepts of supply chain agility are discussed to assist the development of the architecture of the MAS. An overview of the expansive literature on the use of software agents to different supply chain problems is also provided and the main differentiators of MAS with respect to conventional IS are drawn. The third section presents the analytical process for the development of the framework and its features in detail. The fourth section presents the decision support process for that leads to enhanced supply chain agility, using illustrative examples. The paper concludes with a discussion of the limitations and implications and potential extension of the research.

\section{Theoretical development}

\subsection{Supply chain agility}

Agility has been considered a key factor through which a supply chain is capable to adapt to the ever-changing market environment (Christopher and Towill, 2000). A profusion of different definitions of supply chain agility have been developed using conceptual models, normative indexes and interpretive structural modeling (Swafford et al. 2008, Gligor and Holocomb, 2012). It has been approached using several dimensions and measures such as adaptability, range 
(Swafford et al, 2006), market sensitivity, process integration, collaborative planning (Agarwal et al., 2007), demand response (Braunscheidel and Suresh, 2009) alertness, data accessibility, swiftness and flexibility (Gligor et al, 2013). Among the large number of classifications of supply chain agility, two underlying dimensions are commonly expressed.

Firstly, agility denotes the ability of a supply chain to respond swiftly to unexpected or unplanned external circumstances. Responsiveness entails the need to perceive demand without distortions or latencies. The visibility of information is therefore a fundamental characteristic of supply chain responsiveness as it increases demand sensitivity. The inherent uncertainty of supply and demand and associated supply chain risks stipulate the need to be able to swiftly change supply chain operations. The rapid detection and reaction to supply chain risks or unexpected events is a second characteristic of responsiveness. A third dimension of responsiveness relates to the speed with which companies in a supply chain can deliver goods or services (Reinhert and Holweg, 2007).

A second characteristic of supply chain agility lies in the capability of a supply chain to demonstrate significant flexibility; that is the planned ability of collaborating organisations to adapt to expected demand uncertainty and deal with variation, by restructuring their operations, reconfiguring their capabilities, or realigning their strategic objectives (Swafford et al., 2006). In the operations and SCM literatures flexibility is a well-established and complex construct. It is generally manifested as the capability to change capacity to meet changes in customer demand (volume flexibility), capability to change the mix of products/services that it produces at any time (variety flexibility), capability to launch new or revised products (new product flexibility) and the capability to adjust the delivery time of its products or services (delivery flexibility) (Reichhart and Holweg, 2007). Building on the above remarks, the conceptual dimensions against which the capabilities of the proposed MAS are considered in this paper are shown in Figure 1:

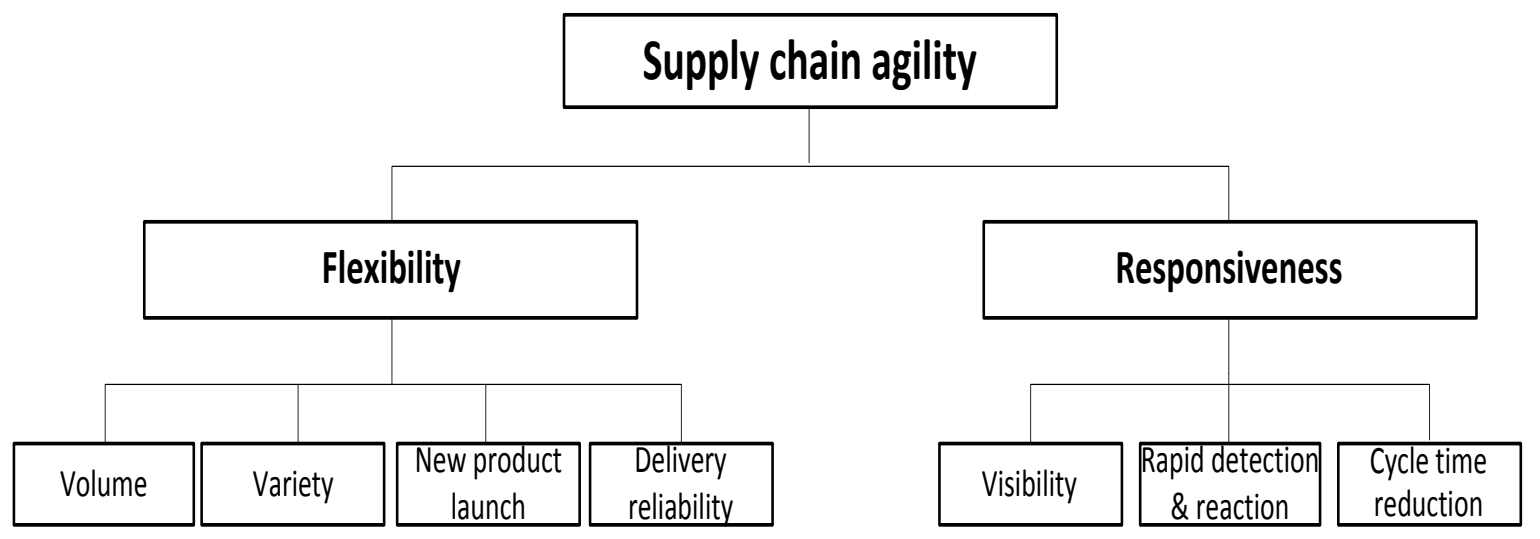

Figure 1-Conceptualisation of supply chain agility

\subsection{Information Systems as facilitators of supply chain agility}

It is well documented in the literature that IT integration is an enabler for supply chain flexibility, agility and eventually higher business performance (Swafford et al, 2008). A wide variety of means have been leveraged in order to achieve SCM effectiveness: e-commerce, enterprise resource planning (ERP), and advance planning systems (APS) (Moyaux and Chaib-draa, 2006).

Successful e-commerce requires state of the art information systems, which can deal with the high complexity of supply chain processes as well as computational capabilities to analyse large the "big data" available to companies today. The latest generation of conventional ERP and APS systems provide a high level of supply chain process integration through internet-based applications (Link and Back, 2015). However this integration is fragmented either to the internal business processes, or to a dyadic context of co-operation (Botta - Genoulaz et al., 2005). Their 
computational realisation of different types of business relationships is also limited (e.g. CPFR, vendor/ buyer relation). Thus, they are bound by an inherent constraint to simultaneously facilitate different "types" of collaboration and to provide efficient transition from one type to another. Little progress has been made to develop solutions for holistic cross-organisational collaboration. A considerable amount of time and funds is required in order to transform conventional e-business systems into collaborative SCM systems, underlying that only organisations that can afford the required high level of investment will be able to achieve responsiveness, and overall to reinforce their competitive advantage. The small parties in a supply chain would face significant constraints to gain benefits from e-business, even if ERP systems manage to totally realise the concept of the extended enterprise. The computational capability of conventional information systems is also limited to analyse voluminous data, or data that is raw or too expensive and complex to integrate and exploit. They can incorporate some elements of data mining analysis, such as clusterisation and correlations of information items can be achieved (Berkovich and Liao, 2012), however their ability to provide real-time analysis of data as well as generate knowledge from big data is nonexistent (Mayer-Schönberger et al., 2013).

\section{The shift of supply chain information technologies to multi agent systems}

For the benefits of e-business to be fully materialised there is a need for information systems that are characterised by low investment costs, adaptability to changes, high level of computational efficiency to manage complex and decentralised supply chains, in order to provide high level of cross organisational collaboration. Multi-agent technology offers the perspective to overcome shortcomings of existing conventional supply chain technologies. MAS are characterised by:

- Autonomy: agents are aware of their environment, operating to some extent without human intervention (Jennings and Woodridge, 1995)

- Social ability: an agent can interact with other agents or humans through the use of an agent communication language (Moyaux and Chaib-draa, 2006).

- Reactivity: agents can perceive their environment and respond to specific changes in this environment (Parunak, 1999)

- Pro-activeness: agents do not simply respond to changes in their environment, but can take action under proactively (Lo et al., 2008).

MAS can also acquire expertise and a computational efficiency in dealing with complex information in combination with easiness of development in a short time frame (Lu and Wang, 2007). With the incorporation of concepts such as agent mining (Twardowski and Ryzko, 2014) and on-the-fly clusterisation (Berkovich and Liao, 2012) re-configuration of the whole supply chain system can become a reality in a timely fashion under a low-cost regime. Furthermore, these benefits can be materialised by incorporating existing legacy systems. For example, an expert system for inventory management or an ERP system can be integrated with agent software.

Several MAS models have been proposed in the literature. Comprehensive reviews of agent based systems are provided by Shen et al. (2006) and Barbati et al. (2012). A summary of models related to SCM is presented in Table 1.

These studies have been very useful in generating insights on how can be applied into provide supply chain solutions. However, they develop/apply MAS to specific supply chain processes. They do not adopt a holistic approach to show the applicability of MAS in enriching the overall supply chain performance and as such they cannot be used to conceptually and empirically approach the archetype of a "truly agile" supply chain. A second limitation is the absence of two significant technologies and methods in their design, which characterise the effectiveness of today's modern IT systems and challenge the development of modern agile supply chains:

1. the collection of a specific series of big data under an autonomous regime 
2. the extraction of meaningful conclusions under a time based and cost efficient manner, using the capabilities of semantic web technologies.

\section{Table 1. Multi agent based systems for Supply Chain Phenomena}

\begin{tabular}{|c|c|}
\hline Author & Focus of study \\
\hline Fox et al. (2000) & $\begin{array}{l}\text { Examination of issues and proposal of solutions for the development of } \\
\text { generic and reusable agent oriented components }\end{array}$ \\
\hline Yung et al. (2000) & $\begin{array}{l}\text { Examination of the integrating capabilities of multi agent technology } \\
\text { and constraint network in improving supply chain efficiency and } \\
\text { transparency }\end{array}$ \\
\hline Lou et al. (2004) & $\begin{array}{l}\text { Development of a multi agent based agile supply chain management } \\
\text { architecture taking into consideration the proximal role of coordination }\end{array}$ \\
\hline Kishore et al. (2006) & $\begin{array}{l}\text { After a synthesis of Integrated Business Information Systems and Multi } \\
\text { Agent Systems bodies of literature, it is proposed a conceptual } \\
\text { framework for multi agent based integrative business information } \\
\text { systems }\end{array}$ \\
\hline (2007) & $\begin{array}{l}\text { An integrated framework aiming to resolve collaborative issues in the } \\
\text { supply chain, leveraging multi agent based collaboration and case based } \\
\text { reasoning }\end{array}$ \\
\hline $\begin{array}{l}\text { Giannakis and Louis } \\
\text { (2011) }\end{array}$ & $\begin{array}{l}\text { A multi agent based framework for managing and mitigating risks in } \\
\text { manufacturing supply chains }\end{array}$ \\
\hline $\begin{array}{l}\text { Lim and Zhang } \\
\text { (2012) }\end{array}$ & $\begin{array}{l}\text { A currency based repetitive bidding mechanism for integrating } \\
\text { production planning and control activities under a cost efficient and } \\
\text { effective basis; aiming to the consolidation of manufacturing agility }\end{array}$ \\
\hline ng (2011) & ilitated \\
\hline Mat & $\begin{array}{l}\text { Supply related tasks are orchestrated according to agents architecture } \\
\text { leveraging a managerial framework; accordingly their performance to } \\
\text { these tasks is being valuated }\end{array}$ \\
\hline l. $(2012)$ & $\begin{array}{l}\text { A multi agent architecture to manage issues related to recycling and } \\
\text { reverse lostics }\end{array}$ \\
\hline $\begin{array}{l}\text { Bearzotti et al. } \\
(2012)\end{array}$ & $\begin{array}{l}\text { An agent based approach for supply chain event management capable of } \\
\text { performing corrective actions leveraging plan's slack under a } \\
\text { collaborative basis. }\end{array}$ \\
\hline $\begin{array}{l}\text { Nikolopoulou and } \\
\text { Ierapetritou (2012) }\end{array}$ & $\begin{array}{l}\text { A simulation based optimization strategy to overcome computational } \\
\text { complexity towards to a better representation of supply chain reality }\end{array}$ \\
\hline Wang et al. (2013) & $\begin{array}{l}\text { An ontology based approach to better utilize agent's } \\
\text { knowledge and accommodate adaptive negotiation decision r }\end{array}$ \\
\hline $\begin{array}{l}\text { Pal and Karakostas } \\
\text { (2014) }\end{array}$ & $\begin{array}{l}\text { A web service and multi agent framework to promote procurement under } \\
\text { a collaborative basis; case based reasoning and rule based reasoning are } \\
\text { being utilized }\end{array}$ \\
\hline $\mathrm{Fu}$ and $\mathrm{Fu}(2015)$ & $\begin{array}{l}\text { A system aiming to the improvement of cost collaborative management } \\
\text { integrating multi agent technology, context aware computing and context } \\
\text { aware reasoning. }\end{array}$ \\
\hline
\end{tabular}

Semantic web technologies permit the representation of knowledge concerning the real meaning of information and services under an automatic regime (Berners-Lee, 2001). The incorporation of semantic web technologies into a MAS can yield significant benefits. Even though they have been leveraged in DSS to solve a multitude of tasks, such as knowledge presentation, web service annotation and task, information sharing and integration (Blomqvist, 2014) and appeared as key 
enabler of automated web service composition (Hatzi et al., 2013), semantic web services inherently do not have the appropriate degree of autonomy, nor capacity to adapt in an everchanging dynamic environment (Shen et al., 2006). In this context, multi agent technology can significantly enrich semantic web services with its inherent characteristics of autonomy and potential for social ability.

The current study aims to shed light on the elements of agent based technology and develop a MAS that could provide enhanced supply chain agility. The study provides a universal agent-based architecture for SCM and incorporates novel aspects that are not addressed in previous works: the incorporation of big data and the semantic web into the proposed MAS.

\section{Research Methodology}

The nature of this study is exploratory and as such an inductive methodology has been adopted for the development and preliminary validation of the SCM MAS. We began the process by incorporating the identified fundamental dimensions of supply chain agility into requirements for the MAS architecture. A detailed MAS architecture was subsequently developed in a way that a software engineer could technically implement the whole system. Two basic steps are required for the technical implementation of the system: the analysis and then the development of the system. However, due to the fact that technical development of the system is not within the research objectives of this study, emphasis has been given to the analysis stage. A sequential process was followed (Kinny et al., 1999), shown in Figure 2. This process is discussed in detail in this section.

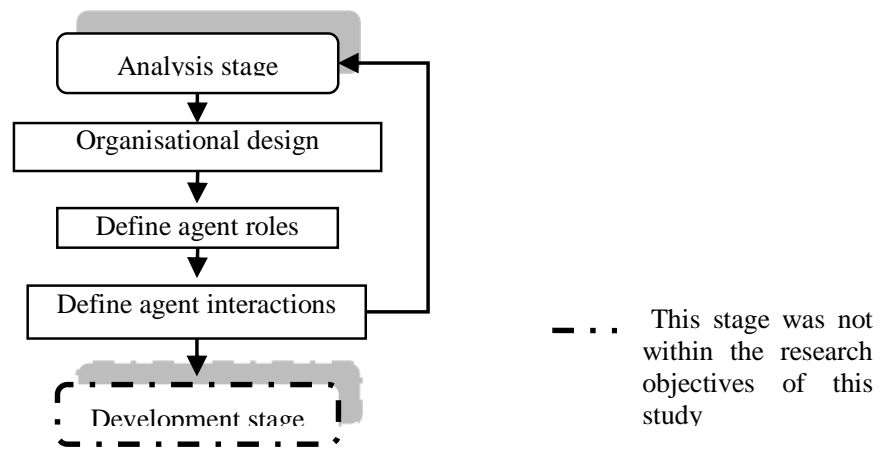

Figure 2 - System development process (adapted from Kinny, et al., 1999)

\subsection{The design of an agent based SCM system}

The first step involved the formulation of the organisational design of the IT system as an artificial society of agents. Then the specific roles for each of these agents was determined and a detailed definition of the responsibilities for each of the agents was prescribed. Finally, the interactions among agents were modelled. A typical supply network was considered consisting of second and first tier suppliers, manufacturers, contractors, LSPs and the ultimate consumer.

The proposed SCM multi agent based system is constituted of the three modules that reflect fundamental supply chain processes: (i) a module of agents responsible for production fulfilment processes (e.g. order management, manufacturer, procurement, logistics, subcontractor and the suppliers' agents), (ii) a module of agents responsible for supply chain event management, and (iii) a module of agents responsible for disruption risk management processes. The system functions as follows: the production fulfilment module coordinates the supply, production and delivery processes of the supply chain. The monitoring module overlooks the smooth functioning of the production fulfillment process and synthesises the supply chain events with the disruption management processes. The disruption risk management module is triggered by a potential disruption that occurs during the order fulfillment process. As the selected supply chain model is considered as customer driven, the order acquisition is taken as the start of the information flow 
for an order in the framework. The analysis in this paper focuses on the production fulfilment process of the entire system and conceptualises and analyses the agent-based processes involved for the coordination of the order, supply, production and delivery processes. The MAS architecture is shown in Figure 3. The dotted lines separate the manufacturer's environment from this of its partners (e.g. suppliers,). A multitude of agents co-exist in the environment of the manufacturer, facilitating the processes of production fulfilment, event and disruption risk management.

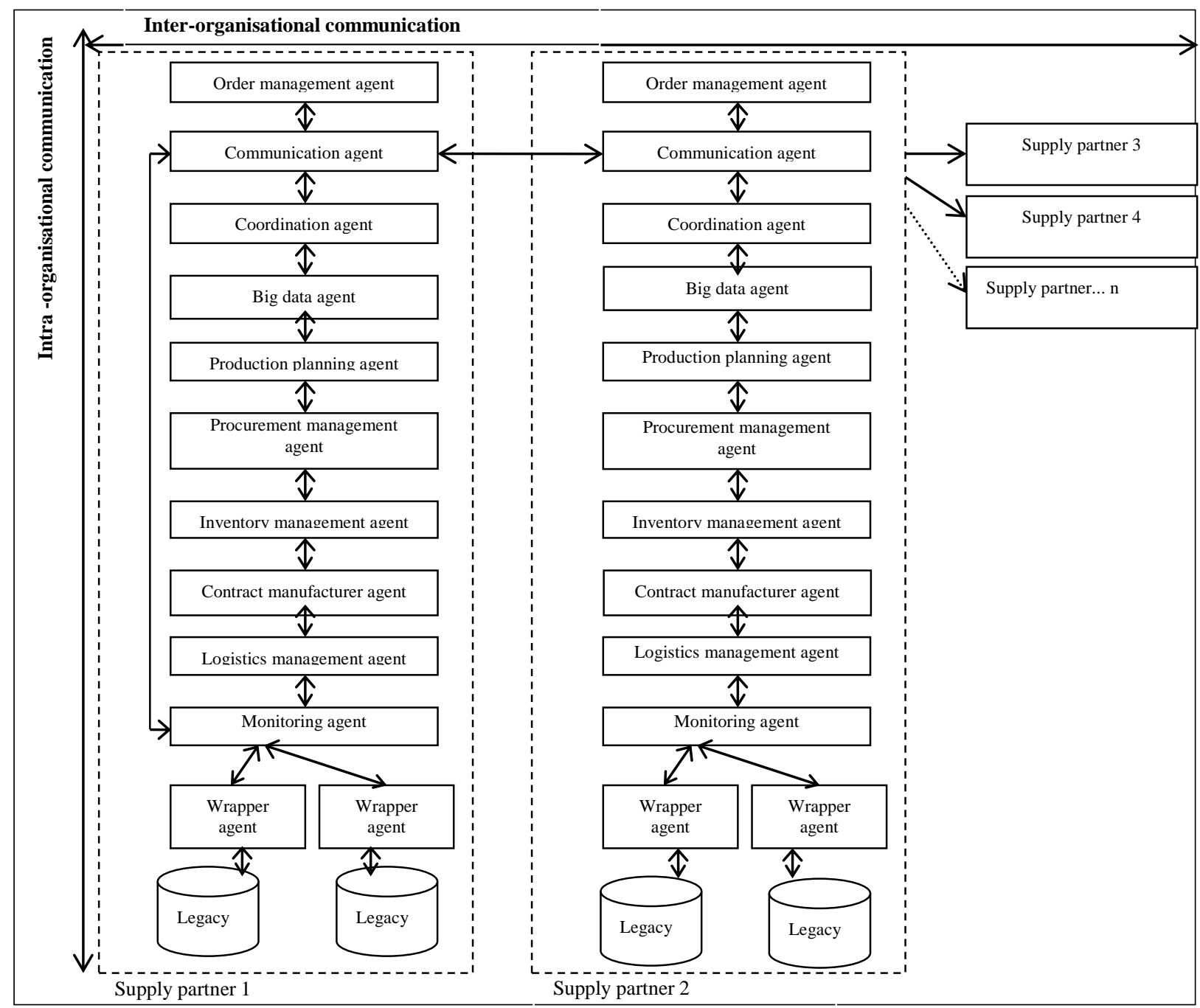

Figure 3 - Agent Society of the proposed MAS framework

A novelty of this organisational design is the incorporation of a big data agent, which includes integrated attributes for semantic web technologies to enable the agents to collect and interpret semantic information for the supply chain partners. The architecture of the big data agent is presented here before the description of the roles and interactions of the agents to show how the big data agent can be integrated with the other agents of the system. Figure 4 illustrates the suggested technological infrastructure. It is constituted of layers, as this is considered as the most suitable for systems aligned with the concept of the extended enterprise (Davis and O' Sullivan, 1999). With this technological infrastructure, several benefits can be accomplished:

- Access from a multitude of sources such as smartphones and notebooks which fulfils the need for real-time and mobile SCM (Soroor et al., 2009). This capability is attributed to the presentation layer of the module.

- Standardised communication formats that have the capability to manage different types of information through the communication layer. This layer is responsible for the transformation of the information received through access layer into a standard format (Lo et al., 2008). 
- Process integration among conventional systems that consolidates the capability for the organisation to conduct e-business, through the application layer (Lo et al., 2008).

- The ontology layer utilises semantic web technology in order to consolidate the level of information integration from the upstream to the downstream of the supply chain, under a cost efficient regime (Lo et al., 2008).

- A complete database so that the upper organisational echelons are facilitated to establish more complicated tasks (Lo et al., 2008), through the database layer. This database stores information related to suppliers, LSPs, customers and disruption risk management.

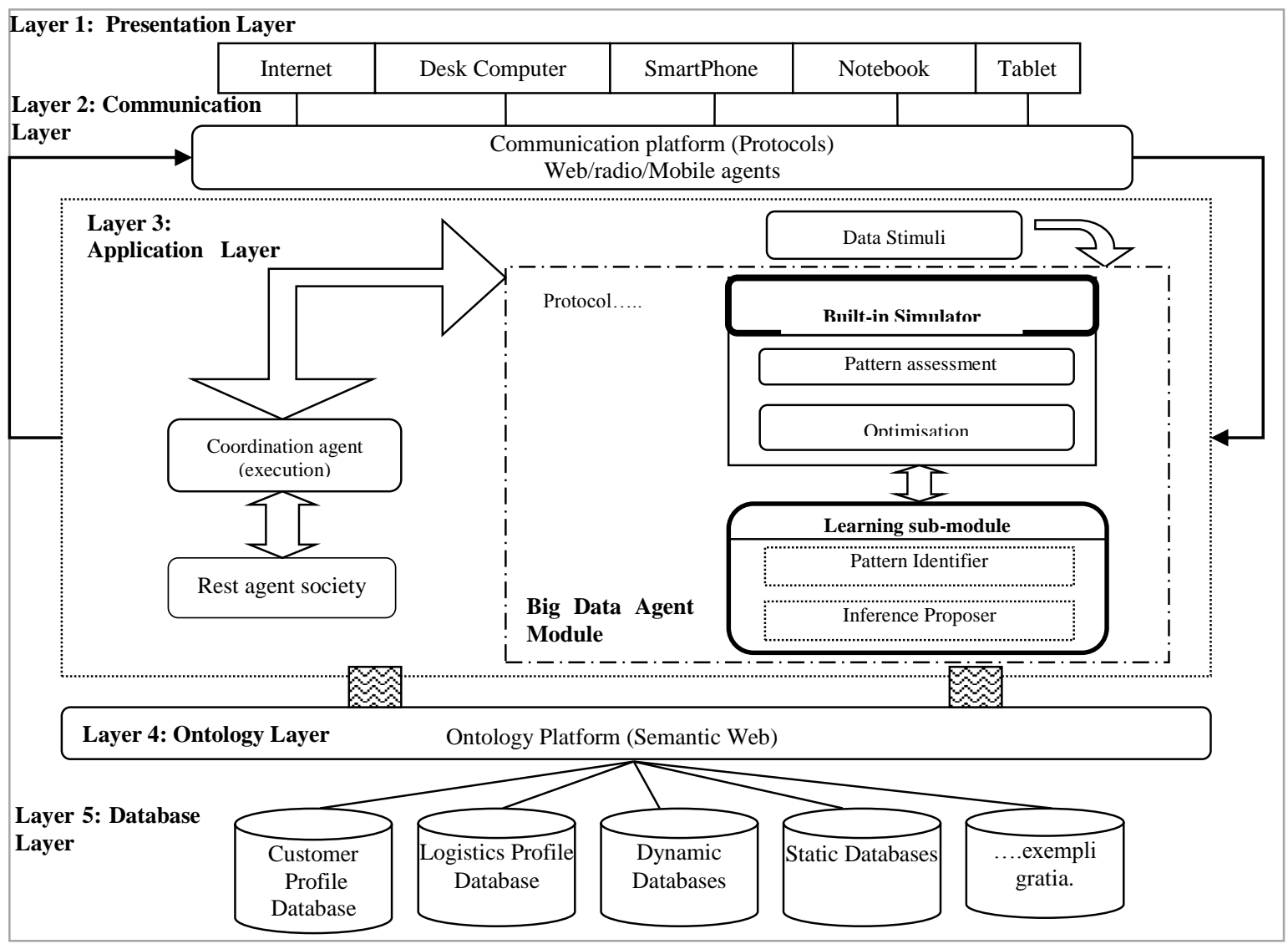

Figure 4 - Layered infrastructure as the big data agent module

\subsection{Roles and interaction amongst the agents}

Based on the organisational design of the MAS and using the logic of fundamental supply chain processes, the specific roles of each agent in the system are defined in this section. The interaction between the proposed agents for the product fulfilment process is discussed in the next section. With case based scenarios we show how this architecture can be applied in practice and how it can enhance each of the identified dimensions of supply chain agility.

Order management agent: it responds to customer requirements, transferring them to proper task agents via the facilitation of coordination agent. It is responsible for receiving customer orders, requests for returns, cancellations and modifications, providing concurrently on-demand status for customer orders. It decomposes an order into order quantity $\left(\mathrm{Q}_{\mathrm{rt}}\right)$, required delivery time $\left(\mathrm{D}_{\mathrm{t}}\right)$ and location $\left(\mathrm{L}_{\mathrm{t}}\right)$. Moreover, it manages the relationship with the customer in order to achieve maximisation of the sales and a higher customer service level. In particular, it processes all the collected orders and subsequently extracts inferences identifying customer preferences and profiles. This information is stored in a customer profile database, for further analysis, to assess a customer's net present value in order to initiate corresponding strategies. This agent therefore has the necessary functionalities to promote customer sensitivity. 
Coordination agent: it synchronises the processes of production fulfillment, supply chain event and disruption risk management. It interacts with other agents for collaboration and communication, it reacts to requests, receives feedback from other agents, and assigns tasks to corresponding agents. This agent facilitates the coordination of agents.

Big data agent: it is responsible for the analysis of big data provided through a series of sources, (public or private databases). It can analyse and interpret information through the semantic web. The case based reasoning of the big data agent is shown in Table 2.

Table 2. Case based reasoning of big data agent

\begin{tabular}{|c|c|c|c|c|c|}
\hline Case no & Pattern trigger & Type of situation identified & Potential action & Expected outcome & Profit \\
\hline $\mathbf{1}$ & Market trend & Opportunity & $\begin{array}{l}\text { Request human } \\
\text { intervention }\end{array}$ & New product development & $\mathrm{XXXX \$}$ \\
\hline 2 & Random correlation & Unknown & Proceed to further process & Pending & Pending \\
\hline 3 & Customer Preference & Opportunity & $\begin{array}{l}\text { Request human } \\
\text { intervention }\end{array}$ & Enrich product variety & XXXX\$ \\
\hline 4 & Inventory & Threat & $\begin{array}{l}\text { Disaggregation of } \\
\text { perpetual inventory }\end{array}$ & $\begin{array}{l}\text { Reduction in labor due to reduction in } \\
\text { misplaced inventory }\end{array}$ & XXXX\$ \\
\hline $\mathbf{n}$ & & & & & \\
\hline
\end{tabular}

Communication agent: it is responsible for the effective communication between the agents of supply chain partners. It facilitates the flow of information among the partners of a supply chain.

Disruption risk management agent: it is responsible for reactive mitigation of prominent risks. It has embedded structures that can propose suggestions for corrective actions as a built in simulator that accounts for the risk assessment and the optimisation processes. Moreover, learning can take place leveraging past decisions as cases for future use in similar situations. In general, it is based on the same mechanics as the big data agent.

Monitoring agent: it is responsible for providing the required monitoring information by gathering and analyzing corresponding data from all the collaborating parties. It has the ability to trigger an alarm, when an abnormal situation occurs. In effect, it provides inter-organisational visibility regarding either normality of abnormality of processes related to the fulfillment of an order. For instance, from a supplier's perspective, it provides supervision of the production process by monitoring the actual production and comparing it to the production schedule.

Production planning agent: it is responsible for acquiring the orders from order management agent. Under the constraints of production and supplier lead times, production capacity $\left(\mathrm{P}_{\mathrm{c}}\right)$, and customer's required delivery time $\left(\mathrm{D}_{\mathrm{t}}\right)$, it generates the production plan. It aims to optimise production cost on behalf of the organisation, having as a constraint a specific customer service level, illustrated upon the parameter of delivery time.

Procurement management agent: It decomposes an order quantity $\left(\mathrm{Q}_{\mathrm{rt}}\right)$, into materials requirements, in order to establish a sourcing plan. It sends these requirements to suppliers, it informs the production planning agent when the delivery of materials is confirmed. It is capable for the supervision and evaluation of supplier performance as well as suppliers' selection. This information is stored to a supplier profile database, in order to consolidate the responsiveness of procurement activities in the future.

Inventory management agent: It provides "visibility" concerning either returned goods customers, or for materials whose their transformation to finished goods has been cancelled due to customers' order modification. The main objective is to reduce obsolescence. 
Manufacturing management agent: it provides feedback (e.g. capacity availability) to the production planning agent and executes the manufacturing processes. It decomposes manufacturing tasks, and then distributes them to the appropriate workshops.

Logistics management agent: it is responsible for the coordination of logistics processes with the objective cost optimisation given the constraints of required delivery time $\left(D_{t}\right)$ and delivery cost $\left(D_{c}\right)$. It retrieves profiles of LSPs, from the LSPs' database, in order to select a suitable LSP. It also receives feedback from customers concerning their performance.

Contract manufacturer agent: it is responsible for selecting reliable contractors on behalf of the manufacturer in case available capacity does not exist in order to meet excessive demand. It retrieves profiles of contract manufacturers from the corresponding database (contract manufacturer profile database), to responsively fulfill needs for contracting.

Wrapper agents: these agents can offer information integration among legacy and agent software. For example, an expert system for inventory management, or an ERP system can be integrated with agent software. The main technique applied is to "wrap" around the legacy code with agent software, so that to "agentify" it into a normal agent. On this basis, the wrapping software is used as a facilitator for the interpretation of messages from agent to legacy systems and vice versa, (Davidsson and Wernstedt, 2002).

The competences and the activity limits of the agents are summarised in Table 3 and in Appendix 1 , analytical information concerning the responsibilities of each agent as well as their interactions are presented.

Table 3 - Summary of roles of agents

\begin{tabular}{|l|l|l|}
\hline Agent Name & Competence & Limit of activity \\
\hline Order management agent & Order acquisition & Intra - organizational \\
\hline Communication agent & Communication & Inter- organizational \\
\hline Big data agent & Data analytics & Intra - organizational \\
\hline Production planning agent & Production plan generation & Intra - organizational \\
\hline Procurement management agent & Souring plan establishment & Intra - organizational \\
\hline Coordination agent & $\begin{array}{l}\text { Synchronization of processes } \\
\text { among agents }\end{array}$ & Intra - organizational \\
\hline Inventory management agent & Reduce obsolescence & Intra - organizational \\
\hline $\begin{array}{l}\text { Manufacturing management } \\
\text { agent }\end{array}$ & $\begin{array}{l}\text { Execution of manufacturing } \\
\text { process }\end{array}$ & Intra - organizational \\
\hline Logistics management agent & LSP's selection & Intra - organizational \\
\hline Monitoring agent & $\begin{array}{l}\text { Monitoring of processes related } \\
\text { to order fulfillment, trigger of } \\
\text { disruption }\end{array}$ & Intra - organizational \\
\hline Wrapper agent & $\begin{array}{l}\text { Integration of MAS with } \\
\text { conventional information } \\
\text { technology }\end{array}$ & Intra - organizational \\
\hline Contract manufacturer agent & Contractor selection & Intra - organizational \\
\hline Disruption management agent & Disruption Management & Intra - organizational \\
\hline
\end{tabular}

\section{Applications of the system and implications for supply chain agility}

A detailed analysis of the interactions and processes among the agents using scenario planning is provided below. The case scenarios that are discussed show how each of the $2^{\text {nd }}$ tier dimensions of supply chain agility can be improved with the use of the proposed MAS. It should be highlighted that learning of the corresponding of each of the scenarios is enhanced through the 
process of case based reasoning as underlined above (Table 3). In this manner, agents are rewarded by their performance in each of the scenarios (by other agents or human intervention), thus decisions per se are identified as good or bad facilitating future use.

\subsection{Flexibility}

Scenario 1: speed in increasing new product development

In this case scenario a major mobile phone manufacturer needs to introduce a new mode ever year. The big data agent is triggered through analysis of big data using market trend patterns, or sourced by social media. Optimisation algorithms for this specific trigger are initiated in order enhance data inference. A plethora of algorithms can be applied, however it would be out of the scope of the paper to discuss in detail the mechanics of these algorithms (see for example Chan et al., 2015). The case is flagged based on the evidence provided by the algorithms. The specific case is explicitly characterised as an "opportunity", which is interpreted to a positive outcome related to new product development. Human intervention is required to further investigate the findings. At this stage, learning takes effect - human interaction assigns to the agents inference of a positive or a negative feedback, labeled as "reward". This will further facilitate the learning process of the agent because it will be evident if the agent's selection (e.g. data set, algorithm) has been correct. The case is saved to the database for further process.

\section{Scenario 2: Product variety enrichment}

In this case an athletic shoes manufacturer needs to reposition one of its product series in the Asian market for which sales have decreased. The big data agent is triggered by the analysis of customer preferences patterns, sourced either from the internet or suppliers. Optimisation algorithms are employed to enhance data inference in a timely manner. Big data is interpreted to previous customer preferences accounting for product reposition. At this stage human intervention is requested to continue the product's repositioning. A "reward" is assigned to the case by human intervention in order to facilitate further learning.

\section{Scenario 3: Dealing with volume variability}

In this case a mobile phone manufacturer aims to introduce a new model. Due to the fact demand is expected to be higher than supplier capacity in minor sub-assemblies, redundant suppliers are contracted to procure the excessive units. In this case the planning agent requires the intervention of the contract manufacturer agent to begin negotiation with suitable contractors. Computational algorithms can be used to coordinate negotiation (van der Putten et al., 2006). Once the negotiation process is finalised the production planning agent is informed to adjust schedule. Units are inspected when received and the contractor is evaluated based on specific key performance indicators (e.g. delivery time, quality).

\section{Scenario 4: Speed in adjusting delivery capability}

In this case the transportation of crucial supplies from a major supplier is examined. The location of the cargo appears static for a significant amount of time. This triggers the big data agent in order to proactively mitigate a prominent delay risk. Subsequently, the disruption risk management is alarmed to initiate the risk management process. Corrective actions are being taken which lead to the allocation of the cargo to a new LSP. When the process is finalised, the disruption risk management assigns a "reward" to the big data agent to facilitate future learning.

\subsection{Responsiveness}

Scenario 5: Increased visibility and cycle time reduction

In this case the minimisation of the bullwhip effect is examined through a typical supply chain constituted of a retailer, wholesaler and a manufacturer. With the assistance of the MAS, process coordination can be enhanced through the real time exchange of information between the agents of the supply chain partners. The retailer's procurement agent communicates with the wholesaler's 
order management agent and the order is decomposed in terms of the actual order (the amount of actual demand) and the amount required for refilling its inventory. Both the wholesaler and the manufacturer have access to retailer's big data agent, facilitating centralised information sharing. As there is real time exchange of information between the supply chain partners and on-going communication about the location of particular shipments, the cycle time of a particular order is reduced.

\section{Scenario 6: Rapid reaction and detection}

In this hypothesised scenario, a manufacturer's big data agent is triggered by a significant inventory aggregation situated in a major's supplier warehouse for the fulfillment of a crucial order. Quantified information is transferred to the disruption management agent to assess the likelihood of a risk event. If the risk cannot be clearly identified, human intervention may be required. Subsequently the disruption agent will be informed by the actions taken by the human intervention to leverage this knowledge to future situations.

\section{Discussion - Shifting the paradigm for data intensive SCM MAS systems.}

The aim of this paper has been to advance knowledge about how organisations can achieve supply chain agility through the leverage of agent based systems that incorporate big data analysis and semantic web services. With the development of the architecture of a MAS system we explicitly provide the foundation of a theoretical bridging among specific concepts/dimensions of supply chain agility, through the comparison of conventional information systems and agent based systems architecture. The case-based scenarios show how several characteristics of the proposed MAS can facilitate information integration, customer sensitivity, process integration and collaborative planning through the mediation of inherent characteristics (e.g. social ability, autonomy, learning responsiveness) and lead to enhanced supply chain agility.

As its software agents can interact with each other as well as humans in a collaborative manner, they can capture and process information in real time and thus lead to better responsiveness. The computational efficiency of the proposed system is superior compared to traditional information systems, due to their inherent capability for decentralisation. This renders the MAS capable to deal with complex supply chain problems. The simple and short nature of the software also makes this information is widely available and accessible to supply chain partners and facilitates collaboration. Information integration can also be facilitated with through the use of wrapper agents with semantic web services. The effects of the MAS on customer sensitivity are also evident. Due to their autonomy, agents can diagnose new opportunities that could enrich customer value. Their learning capability can increase the reactivity of a company for the creation of new, customer-driven products. The incorporation of semantic web services of the proposed system can further increase customer sensitivity. The real-time perception of the business environment, combined with the learning ability of the agents can lead to process integration through proactive adjustment of manufacturing process, thereby facilitating decision making processes. Finally, collaborative planning could be enhanced as the social ability and learning capabilities of the agents can lead to the development of trust. This can lead to better coordination and minimisation of the bullwhip effect. Through the use of semantic web services the accumulation of big data can be available throughout the supply chain, providing thus valuable information to all the participating parties.

The proposed MAS has linkages to other studies within the field of agent based supply chain management in terms of tasks decomposition into agents and coordination mechanisms. For example, the use of social media as a proxy to facilitate new product development has also been used by Chan et al. (2015) however the study was not within the context of agent based supply chain management. Increased visibility and cycle time reduction sub-dimension coordination 
mechanism was influenced by the research conducted by Moyaux et al. (2003) to ameliorate the bullwhip effect.

Based on the presentation of the hypothesised scenarios, Table 4 summarises the capabilities of the proposed MAS in relation to salient supply chain agility measures and provides its potential comparative advantage over conventional IT tools for effective SCM. As this analysis is based on conceptual rationalisation of the potential benefits of the proposed MAS and evidence from the literature about certain limitations of conventional IT systems, empirical research is needed to test with quantifiable data the actual performance benefits for supply chain agility in real organisations. It should be emphasised that the paper does not advocate superiority of MAS over conventional IS. It posits that the autonomous decision making authority of MAS, combined with built in capabilities for big data analytics, can enhanced supply chain agility.

\section{Table 4 - MAS Vs conventional technology for agile supply chain management}

\begin{tabular}{|c|c|c|c|c|c|}
\hline Element & Ability & MAS & $\begin{array}{l}\text { Conventi } \\
\text { onal IT }\end{array}$ & Key Difference & Overview \\
\hline \multirow{4}{*}{$\begin{array}{l}\text { Information } \\
\text { technology } \\
\text { and } \\
\text { integration }\end{array}$} & $\begin{array}{l}\text { Capture demand } \\
\text { information } \\
\text { immediately }\end{array}$ & High & Low & $\begin{array}{l}\text { Social Ability, } \\
\text { Responsiveness }\end{array}$ & $\begin{array}{l}\text { An agent can interact with other agents or humans through } \\
\text { the use of an agent communication language. }\end{array}$ \\
\hline & Virtual Connection & High & Low & $\begin{array}{l}\text { Computational } \\
\text { efficiency, scalability }\end{array}$ & $\begin{array}{l}\text { MAS can easily deal with complex problems due to their } \\
\text { inherent capability for decentralization. }\end{array}$ \\
\hline & $\begin{array}{l}\text { Information } \\
\text { accessible to supply } \\
\text { chain wide }\end{array}$ & High & Low & $\begin{array}{l}\text { High computational } \\
\text { efficiency, nature of } \\
\text { software }\end{array}$ & $\begin{array}{l}\text { The realization of a holistic cross - organizational } \\
\text { collaboration is possible. The short and simple nature of } \\
\text { software is an important enable of this future. In addition }\end{array}$ \\
\hline & $\begin{array}{l}\text { Integrate with } \\
\text { Semantic Web } \\
\text { Services }\end{array}$ & High & Low & $\begin{array}{l}\text { Easiness of integration } \\
\text { methods under a cost } \\
\text { efficient manner }\end{array}$ & $\begin{array}{l}\text { Overall, the use of wrapper agents can significantly facilitate } \\
\text { integration with semantic web services. Thus, agents can } \\
\text { achieve a better perception of Internet based objects. It is } \\
\text { prominent that the leverage of semantic web services leads to } \\
\text { a higher degree of information integration. }\end{array}$ \\
\hline \multirow{3}{*}{$\begin{array}{l}\text { Customer / } \\
\text { marketing } \\
\text { sensitivity }\end{array}$} & $\begin{array}{l}\text { Perceive } \\
\text { opportunities to } \\
\text { increase customer } \\
\text { value }\end{array}$ & High & Low & $\begin{array}{l}\text { Pro-activeness, social } \\
\text { ability, autonomy }\end{array}$ & $\begin{array}{l}\text { MAS due to their autonomy can diagnose new opportunities } \\
\text { that could enrich customer value. Genetic algorithms leverage } \\
\text { seems an important facilitator. }\end{array}$ \\
\hline & $\begin{array}{l}\text { Customer-driven } \\
\text { products }\end{array}$ & Robust & Fragile & $\begin{array}{l}\text { Reactivity, social } \\
\text { ability, pro-activeness }\end{array}$ & $\begin{array}{l}\text { MAS can robustly response to customer preferences due to } \\
\text { their inherent learning capabilities }\end{array}$ \\
\hline & $\begin{array}{l}\text { Incorporate } \\
\text { Semantic Web } \\
\text { Services } \\
\end{array}$ & High & Low & $\begin{array}{l}\text { Social ability, } \\
\text { autonomy, reactivity }\end{array}$ & $\begin{array}{l}\text { Overall agents through their learning ability can leverage } \\
\text { perceptions taken from semantic web services in order to } \\
\text { achieve a higher level of customer sensitivity. }\end{array}$ \\
\hline \multirow{3}{*}{$\begin{array}{l}\text { Process } \\
\text { Integration \& } \\
\text { Performance } \\
\text { management }\end{array}$} & $\begin{array}{l}\text { Facilitate Rapid } \\
\text { decision making }\end{array}$ & $\begin{array}{l}\text { Real- } \\
\text { time }\end{array}$ & Slow & \begin{tabular}{|l|} 
Autonomy, pro- \\
activeness, re-activity, \\
social ability , system \\
re-configurability \\
\end{tabular} & $\begin{array}{l}\text { MAS can demonstrate real - time responsiveness capability. } \\
\text { In fact, learning ability is an important facilitator of this } \\
\text { capability. Moreover, they can be reconfigured with easiness } \\
\text { to new business processes. }\end{array}$ \\
\hline & $\begin{array}{l}\text { Pro-actively update } \\
\text { the mix of available } \\
\text { supply chain } \\
\text { processes }\end{array}$ & $\begin{array}{l}\text { Real- } \\
\text { time }\end{array}$ & Slow & $\begin{array}{l}\text { Autonomy, pro- } \\
\text { activeness, social } \\
\text { ability }\end{array}$ & $\begin{array}{l}\text { MAS can real-time perceive their environment (e.g. software } \\
\text { agents, manufacturing equipment). In this manner, they can } \\
\text { real time adjust manufacturing processes pro-actively }\end{array}$ \\
\hline & $\begin{array}{l}\text { Leverage Semantic } \\
\text { Web Services }\end{array}$ & High & Low & Learning ability & $\begin{array}{l}\text { Overall, performance management can be enriched with big } \\
\text { data interpreted under a meaningful way. A series of } \\
\text { unforeseen performance measures can be revealed as } \\
\text { mediator factors to performance }\end{array}$ \\
\hline \multirow{3}{*}{$\begin{array}{l}\text { Collaborative } \\
\text { planning }\end{array}$} & $\begin{array}{l}\text { Representation of } \\
\text { trust based } \\
\text { relationships with } \\
\text { suppliers/customers } \\
\end{array}$ & High & Low & $\begin{array}{l}\text { Social ability, learning } \\
\text { capability }\end{array}$ & $\begin{array}{l}\text { Based on previous research trust among partners can be } \\
\text { represented among agents. In this manner trust can be } \\
\text { represented among agents matching reality. }\end{array}$ \\
\hline & $\begin{array}{l}\text { Reduce Bullwhip } \\
\text { effect - data } \\
\text { accuracy }\end{array}$ & High & Low & $\begin{array}{l}\text { Pro-activeness, } \\
\text { autonomy }\end{array}$ & $\begin{array}{l}\text { Agents through the use of learning algorithms can achieve } \\
\text { solutions that approach to optimal, even if there is no high } \\
\text { level of information sharing }\end{array}$ \\
\hline & $\begin{array}{l}\text { Leverage Semantic } \\
\text { Web Services }\end{array}$ & High & Low & $\begin{array}{l}\text { Computational } \\
\text { efficiency, autonomy, } \\
\text { learning capability }\end{array}$ & $\begin{array}{l}\text { Semantic Web services can facilitate the representation of } \\
\text { trust based relationships. Moreover, they can facilitate big } \\
\text { data collection from a series of Internet sources. The data } \\
\text { inference through agents learning capabilities can provide } \\
\text { meaningful information for all the nodes of the supply chain }\end{array}$ \\
\hline
\end{tabular}

\section{Implications of the study}


Based on the conceptual grounding of supply chain agility, the development of the architecture of the MAS and the analysis of the case-based scenarios, several implications for theory and practice can be drawn. Whilst the case scenarios do not seek to be representative and generalisable examples, they suggest a number of interesting themes that deserve further investigation.

Implication for SCM theory - Redefining the relationship between agility and complexity

In SCM literature there is a consensus that there is a trade-off between supply chain agility and complexity (Prater et al., 2001, Swafford et al., 2008). Theory suggests that the inherent complexity and subsequent supply chain risks that arise in global supply chains, impose limiting factors to the overall level of supply chain agility (flexibility, speed and responsiveness). Therefore for an existing level of complexity in a supply chain there is an optimal level of supply chain agility that can be achieved. The main theoretical proposition of this study is that the use of MASs that incorporate the semantic web and big data technologies can enhance supply chain agility despite the increased complexity of supply chains (Figure 5). As the proposed MAS enables IT integration across complex supply chains this leads to better communication, shared product design information and greater responsiveness of the procurement and manufacturing processes that yields shorter lead times. This leads to higher levels of agility, despite the increased complexity of the supply chain.

In Figure 5 the actual (point C) vs theoretical (point B) enhanced efficient frontiers are shown, to reflect the impact of the law of diminishing returns; the fact that realistic improvements in supply chain will be delimited by contingency factors such as the effects of potential risks that exist in global supply chain. These supply chain risks originate in global transportation networks that may lead to unexpected delays, political instability and border controls, security breaches of the use of information systems, as well as environmental risks. All these may impose limiting factors to the overall level of supply chain agility.

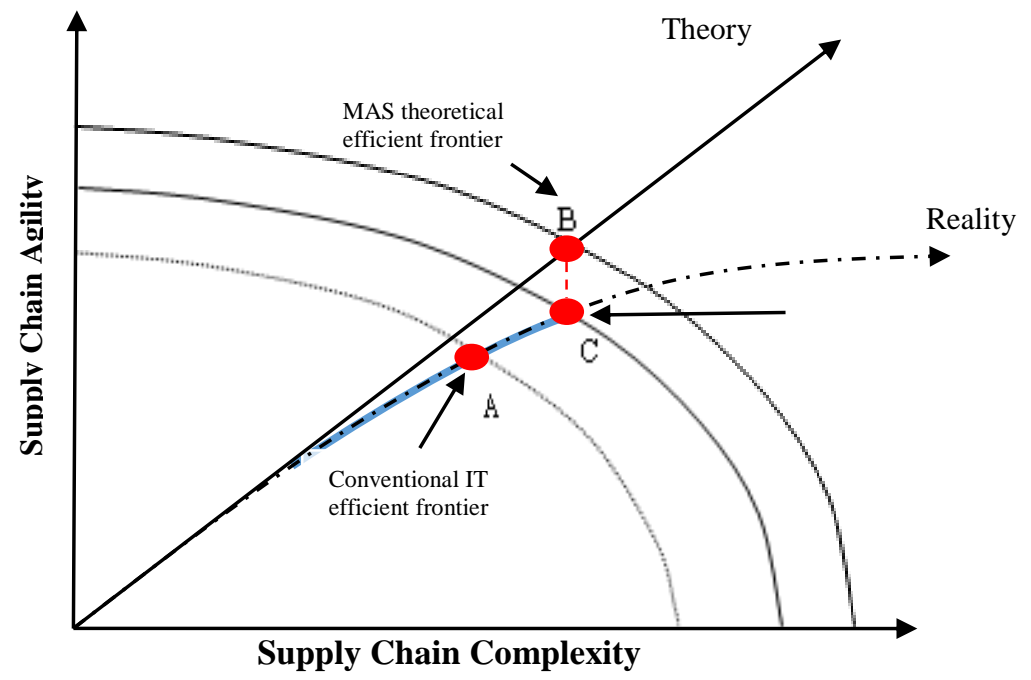

Figure 5 - Overcoming the trade-off between complexity and supply chain agility

The effect of MAS on supply chain agility has direct implications on the way that process integration and coordination between supply chain partners may be achieved as well as the way that supply chain relationships may be constructed. As MAS are generally cheaper than traditional information systems, they can be adopted even by small suppliers which would not normally invest in expensive legacy systems. This may incentivise a new wave of increased global sourcing by large corporations, provided that security concerns that are naturally imposed by large information systems can be carefully addressed. 


\section{Managerial Implications}

One of the managerial implications of the proposed MAS is that it provides integrated capabilities for production, supply chain event and disruption risk management under a collaborative basis. It enables an organisation to inform its customers about the precise delivery date, taking into consideration transportation and production lead times. For instance, when a customer places an order, suppliers and logistics service providers are contacted in real time in order to provide specific delivery date.

The existence of a supply chain event management system provides the perspective for the reinforcement of the collaboration among partners. In particular, after a customer confirms its order, a monitoring procedure is initiated across the partners that are linked to the fulfillment of this order. A monitoring agent is generated to each of the partners and when an abnormal event is identified to a specific supplier, a procedure for corrective action is initiated through the disruption risk management agent. The proposed framework has also the potential to provide customer sensitivity, essential ingredient for a truly agile supply chain (Christopher and Towill, 2001), through the identification of trends of customer needs by the analysis of customer profiles situated in customer profile database.

\section{Conclusion}

Multi agent technology provides a promising opportunity to meet the needs of modern SCM for high level of cross organisational collaboration and decentralisation of operations. In this paper we propose a novel approach to the design of inter-organisational MASs. We show how the proposed system can lead to enhanced supply chain agility, despite the increased complexity of global supply chains.

We see a number of contributions of our work to the body of literature that discusses the use of MAS for business processes improvements. First, the proposed model provides a holistic decision support framework for fundamental supply chain business processes. Adding to previous works (Giannakis and Louis, 2011; Bearzotti et al., 2012), we include business rules for product fulfillment, supply chain event management as well as disruption management. Secondly, we design the SCM MAS as a distributed inter-organisational information system, whilst maintaining each supply chain member's autonomy. In addition to the typical MAS models found in the literature, we incorporate a big data ontology that can be used to process information of semantic web applications in real time as well as offline, under an autonomous and synergetic regime.

We discuss how this approach is well suited for applications where collaborative supply chain processes are needed and how this enhances a fundamental supply chain performance construct supply chain agility. In this way we theoretically link the big data analytics and supply chain performance (Waller and Fawcett, 2013). We hope that this may be a useful learning tool for the development of semantic web languages such as resource description framework (RDF) web ontology language (OWL) and extensible markup language (EML).

The lack of empirical research in the application of the framework provides a limitation of our propositions. Our aim in this study however has been to design and explore, rather explain or confirm through empirical evidence, operational or financial benefits. Further research is needed to identify and confirm the potential benefits of the MAS. Only through empirical studies quantification of the actual increment of the efficient frontier between agility and complexity can be achieved.

Future studies could also focus on theory building as well. For example, an inquiry on how agentbased technology can foster supply chain sustainability, or an inquiry about the how certain 
attributes of senior supply chain managers (age, professional background) influence the incorporation and implementation of agent based technology in decision making would be useful to identify the proclivity of potential organisations to use MAS as a decision support tool. Industries with short business cycles such as retaining, but also industries with high level of variability such as oil and gas industry would be useful contexts to probe the usefulness of a MAS.

\section{References}

Agarwal, A., Shankar, R. \& Tiwari, M. (2007). Modeling agility of supply chain, Industrial Marketing Management, 36: 443-457

Akkermans, H., Bogerd, P., Yücesan, E. \& van Wassenhove, L.N. (2003) "The impact of ERP on supply chain management: exploratory findings from a european delphi study. European Journal of Operational Research 146 (2), 284-301.

Barbati, M., Bruno, G., \& Genovese, A. (2012). Applications of agent-based models for optimization problems: A literature review. Expert Systems with Applications, 39(5), 6020-6028.

Bearzotti, L. A., Salomone, E., \& Chiotti, O. J. (2012). An autonomous multi-agent approach to supply chain event management. International Journal of Production Economics, 135(1), 468-478.

Berkovich, S. and Liao, D. (2012). On clusterization of big data streams, $3^{\text {rd }}$ International conference on Computing for Geospatial research and applications, New York.

Berners-Lee, T., Hendler, J., \& Lassila, O. (2001) “The semantic web”, Scientific American, 284 (5), 28-37

Blomqvist, E. (2014). The use of Semantic Web technologies for decision support-a survey. Semantic Web, 5(3), 177-201.

Botta-Genoulaz, V., Grabot, B. and Millet, P.A. (2005) A survey on the recent research literature on ERP systems, Computers in Industry 56 (6), 510-522.

Braunscheidel, M.J., and Suresh, N.C. 2009. "The Organisational Antecedents of a Firm's Supply Chain Agility for Risk Mitigation and Response.” Journal of Operations Management 27 (2),119-40.

Chan, H. K., Wang, X., Lacka, E., \& Zhang, M. (2015) "A Mixed-Method Approach to Extracting the Value of Social Media Data" Production and Operations Management.

Christopher, M. and Towill, D.R. (2000) 'Supply chain migration from lean and functional to agile and customized'. Supply Chain Management: An International Journal, 5 (4), 206- 213.

Christopher, M. and Towill, D., 2001. An integrated model for the design of agile supply chains. International Journal of Physical Distribution \& Logistics Management, (31) 4, 235-246.

Christopher, M., \& Lee, H. (2004). Mitigating supply chain risk through improved confidence. International journal of physical distribution \& logistics management, 34(5), 388-396.

Davidsson, P. and Wernstedt, F. (2002) "Software agents for bioprocess monitoring and control". Journal of Chemical Technology and Biotechnology, 77, 761-766.

Davis, M. and O'Sullivan, D.C. (1999) "Systems design framework for the extended enterprise". Production Planning and control, 10 (1), 3-18.

Fox, M.S., Barbuceanu, M., and Teigen, R. (2000) "Agent-Oriented Supply Chain Management" International Journal of Flexible Manufacturing Systems, 12 (2/3), 165-188.

$\mathrm{Fu}$, J., \& Fu, Y. (2015). An adaptive multi-agent system for cost collaborative management in supply chains. Engineering Applications of Artificial Intelligence, 44, 91-100.

Gattorna, J. (2006) Living supply chains: how to mobilize the enterprise around delivering what your customers want. Pearson Education.

Giannakis, M., \& Louis, M. (2011) "A multi-agent based framework for supply chain risk management", Journal of Purchasing and Supply Management, 17(1), 23-31.

Gligor, D. M., \& Holcomb, M. C. (2012) "Understanding the role of logistics capabilities in achieving supply chain agility: a systematic literature review" Supply Chain Management: An International Journal, 17 (4), 438-453. 
Gligor, D.M, Holcomb, M.C, and Stand, T.P (2013) "A multidisciplinary approach to supply chain agility: conceptualization and scale development", Journal of Business Logistics, 34(2): 94-108

Hatzi, O., Vrakas, D., Bassiliades, N., Anagnostopoulos, D., \& Vlahavas, I. (2013). The PORSCE II framework: Using AI planning for automated semantic web service composition. The Knowledge Engineering Review, 28 (2), 137-156.

Jennings, N. R. and Wooldridge, M. (1995) "Intelligent agents: Theory and practice" Knowledge Engineering Review 10 (2), 115-152.

Kinny, D., Jennings, N.R. and Woodridge, M. (1999) "A methodology for agent oriented analysis and design". Autonomous agents, USA: Seattle.

Kishore, R., Zhang, H., \& Ramesh, R. (2006). Enterprise integration using the agent paradigm: foundations of multi-agent-based integrative business information systems. Decision Support Systems, 42(1), 48-78.

Kwon, O., Im, G. P, and Lee K. C. (2007) "MACE-SCM: A multi-agent and case-based reasoning collaboration mechanism for supply chain management under supply and demand uncertainties" Expert Systems with Applications 33, 690-705

Li, J., \& Sheng, Z. (2011) "A multi-agent model for the reasoning of uncertainty information in supply chains". International Journal of Production Research, 49 (19), 5737-5753

Lim, M. K., \& Zhang, Z. (2012) "A multi-agent system using iterative bidding mechanism to enhance manufacturing agility" Expert systems with applications, 39 (9), 8259-8273.

Link, B., \& Back, A. (2015) "Classifying systemic differences between software as a service-and onpremise-enterprise resource planning" Journal of Enterprise Information Management, 28 (6), 808-837.

Lo, W., Hong, T., Jeng, R. (2008) "A framework of e-SCM multi-agent systems in the fashion industry", International Journal of Production Economics, 114 (2), 594-614.

Lou, P., Zhou, Z.D. Chen, Y.P. and Ai, W. (2004) "Study on multi-agent-based agile supply chain management" International Journal Advanced Manufacturing Technology 23 (3/4), 197-203.

Lu, L., and Wang, G. (2007) "A study on multi-agent supply chain framework based on network economy" Computers and Industrial Engineering, 54 (2), 288-300

Manuj, I., and Mentzer, J., 2008. Global supply chain risk management strategies. International Journal of Physical Distribution and Logistics Management 38 (3), 192-223.

Mattia, A. (2012). A Multi-Dimensional View of Agent-Based Decisions in Supply Chain Management. Communications of the IBIMA, 2012, 1.

Mayer-Schönberger, V., and Kenneth, C. (2013) Big data: A revolution that will transform how we live, work, and think. Houghton Mifflin Harcourt.

Mishra, N., Kumar B., \& Chan, F.T. (2012) "A multi-agent architecture for reverse logistics in a green supply chain, International Journal of Production Research, 50 (9), 2396-2406

Moyaux, T., and Chaib-draa, B. (2006) "Supply chain management and multi agent systems: An overview". In: Chaib-draa, B. and Müller, J.P. (Eds.) Multiagent-Based Supply Chain Management, Springer, USA

Nikolopoulou, A., \& Ierapetritou, M. G. (2012) "Hybrid simulation based optimization approach for supply chain management" Computers \& Chemical Engineering, 47, 183-193.

Pal, K., \& Karakostas, B. (2014). A multi agent-based service framework for supply chain management. Procedia Computer Science, 32, 53-60.

Parunak, H.V. (1999) "Industrial and practical applications of DAI" In: Weiss, G., (ed.). Multi agent Systems - A Modern Approach to Distributed Modern Approach to Artificial Intelligence. The MIT Press, Cambridge, Massachusetts, London: England.

Prater, E., Biehl, M., \& Smith, M. A. (2001). "International supply chain agility: tradeoffs between flexibility and uncertainty" International Journal of Operations \& Production Management, 21 (5/6), 823839.

Reichhart, A. and Holweg, M. (2007) "Creating the customer-responsive supply chain: a reconciliation of concepts". International Journal of Operations \& Production Management, 27 (11): 1144-1172. 
Shen, W., Hao, Q., Yoon, H. J., \& Norrie, D. H. (2006). Applications of agent-based systems in intelligent manufacturing: An updated review. Advanced engineering INFORMATICS, 20(4), 415-431.

Stone, P. and Veloso, M., 2000. Multi agent Systems: A Survey from a Machine Learning Perspective. Autonomous Robots 8 (3), 345-383.

Swafford, P. M., Ghosh, S., \& Murthy, N. (2006) "The antecedents of supply chain agility of a firm: scale development and model testing" Journal of Operations Management, 24 (2), 170-188

Swafford, P. M., Ghosh, S., \& Murthy, N. (2008). Achieving supply chain agility through IT integration and flexibility. International Journal of Production Economics, 11, 6(2), 288-297.

Soroor, A. et al. (2009) "Initiating an state of the art system for real time supply chain coordination" European Journal of Operational Research, 196 (2) 635-650.

Twardowski, B., \& Ryzko, D. (2014, August). Multi-agent architecture for real-time Big Data processing. In 2014 IEEE/WIC/ACM International Joint Conferences on Web Intelligence (WI) and Intelligent Agent Technologies (IAT)(pp. 333-337). IEEE.

Van Der Putten, S., Robu, V., La Poutré, H., Jorritsma, A., \& Gal, M. (2006). Automating supply chain negotiations using autonomous agents: a case study in transportation logistics. In Proceedings of the fifth international joint conference on Autonomous agents and multiagent systems (pp. 1506-1513).

Waller, M. A., \& Fawcett, S. E. (2013). Data science, predictive analytics, and big data: a revolution that will transform supply chain design and management.Journal of Business Logistics, 34(2), 77-84.

Wang, G., Wong, T. N., \& Wang, X. (2013). An ontology based approach to organize multi-agent assisted supply chain negotiations. Computers \& Industrial Engineering, 65(1), 2-15.

Yung, S. K., Yang, C. C., Lau, A. S., \& Yen, J. (2000). Applying Multi Agent Technology to Supply Chain Management. J. Electron. Commerce Res., 1(4), 119-132. 


\section{Appendix 1 - Responsibilities and interactions of agents}

\begin{tabular}{|c|c|c|c|c|c|c|c|}
\hline & Agents & Responsibility & Event Trigger & $\begin{array}{ll}\text { Inputs } \\
\end{array}$ & Constraints & Output & Interaction \\
\hline \multirow{8}{*}{ 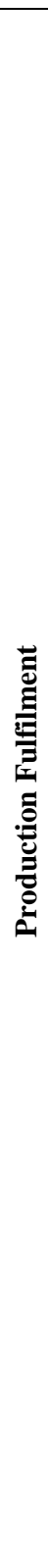 } & $\begin{array}{l}\text { Coordina } \\
\text { tion } \\
\text { agent } \\
\text { (CA) }\end{array}$ & $\begin{array}{l}\text { Coordination of: } \\
\text { - Production fulfilment } \\
\text { - Event management } \\
\text { - Disruption risk mgmt. }\end{array}$ & \multirow{3}{*}{$\begin{array}{l}\text { Customer's } \\
\text { order }\end{array}$} & & & & $\begin{array}{l}\text { OMA, PPA, } \\
\text { DRA, CMA, } \\
\text { IMA }\end{array}$ \\
\hline & \begin{tabular}{|l|} 
Order \\
manage \\
ment \\
agent \\
(OMA) \\
\end{tabular} & Order acquisition & & \begin{tabular}{|c|} 
- Order \\
quantity \\
- Delivery time \\
- Delivery \\
Location \\
\end{tabular} & - & $\begin{array}{l}\text {-Price } \\
\text { - Delivery time } \\
\text {-Delivery location } \\
\text {-Potential } \\
\text { discounts } \\
\end{array}$ & \multirow[b]{2}{*}{$\begin{array}{c}\text { Coordination } \\
\text { agent }\end{array}$} \\
\hline & $\begin{array}{l}\text { Producti } \\
\text { on } \\
\text { planning } \\
\text { agent } \\
\text { (PPA) }\end{array}$ & Production Plan & & $\begin{array}{c}\text { - Order } \\
\text { quantity } \\
\text { - Delivery time }\end{array}$ & $\begin{array}{l}\mid \text { Production } \\
\text { capacity } \\
- \text { Suppliers } \\
\text { lead time } \\
\text {-Required } \\
\text { delivery } \\
\text { time }\end{array}$ & Production plan & \\
\hline & \begin{tabular}{|l|} 
Manufac \\
turing \\
manage \\
ment \\
agent \\
(MMA) \\
\end{tabular} & $\begin{array}{l}\text { Execution of } \\
\text { manufacturing } \\
\text { processes }\end{array}$ & $\begin{array}{l}\text { Production } \\
\text { Planning }\end{array}$ & $\begin{array}{l}\text { - Order } \\
\text { quantity } \\
\text { - Delivery time }\end{array}$ & $\begin{array}{l}\text { - Capacity } \\
\text {-Status of } \\
\text { manufacturi } \\
\mathrm{ng} \\
\text { machines }\end{array}$ & Available capacity & $\begin{array}{l}\text { Production } \\
\text { planning agent }\end{array}$ \\
\hline & \begin{tabular}{|l|} 
Inventor \\
y \\
manage \\
ment \\
agent \\
(IMA) \\
\end{tabular} & $\begin{array}{l}\text { Visibility of } \\
\text { inventories }\end{array}$ & $\begin{array}{l}\text { Inventories } \\
\text { that are } \\
\text { about to } \\
\text { become } \\
\text { obsolete }\end{array}$ & $\begin{array}{l}\text { Time frame for } \\
\text { obsolete } \\
\text { inventories }\end{array}$ & - & $\begin{array}{l}\text { Notification for the } \\
\text { inventories that are } \\
\text { about to become } \\
\text { obsolete }\end{array}$ & $\begin{array}{l}\text { Production } \\
\text { planning agent, } \\
\text { disruption risk } \\
\text { management } \\
\text { agent }\end{array}$ \\
\hline & \begin{tabular}{|l|} 
Contract \\
manufact \\
urer \\
agent \\
(CMA) \\
\end{tabular} & $\begin{array}{l}\text { - Contractor selection } \\
\text { - Negotiation }\end{array}$ & $\begin{array}{l}\text { Insufficient } \\
\text { capacity }\end{array}$ & $\mid \begin{array}{l}\text { - Order } \\
\text { quantity } \\
\text { - Required } \\
\text { delivery time }\end{array}$ & $\begin{array}{l}\text {-Production } \\
\text { capacity } \\
\text {-Suppliers } \\
\text { lead time }\end{array}$ & $\begin{array}{l}\text {-Price } \\
\text {-Delivery time } \\
\text {-Delivery location }\end{array}$ & $\begin{array}{l}\text { Coordination } \\
\text { agent }\end{array}$ \\
\hline & \begin{tabular}{|l|} 
Procure \\
ment \\
manage \\
ment \\
agent \\
(PMA) \\
\end{tabular} & $\begin{array}{l}\text { - Negotiation } \\
\text { - Supplier Selection }\end{array}$ & $\begin{array}{l}\text { Insufficient } \\
\text { inventories, } \\
\text { supplier } \\
\text { Disruption }\end{array}$ & $\begin{array}{l}\text { Order } \\
\text { quantity } \\
\text { Delivery } \\
\text { time }\end{array}$ & $\begin{array}{l}\text {-Suppliers } \\
\text { lead times }\end{array}$ & $\begin{array}{l}\text { Confirmation of } \\
\text { the procurement } \\
\text { agreement }\end{array}$ & $\begin{array}{l}\text { Production } \\
\text { planning agent }\end{array}$ \\
\hline & \begin{tabular}{|l|} 
Logistics \\
manage \\
ment \\
agent \\
(LMA)
\end{tabular} & $\begin{array}{l}- \text { Negotiation } \\
\text { - LSP selection }\end{array}$ & $\begin{array}{l}\text { - Distribution } \\
- \text { Supplier } \\
- \text { Contractor } \\
\text { Disruption }\end{array}$ & $\mid \begin{array}{l}\text { Delivery } \\
\text { time } \\
- \text { Delivery cost }\end{array}$ & $\begin{array}{l}- \text { Transportati } \\
\text { on lead } \\
\text { times }\end{array}$ & $\begin{array}{l}\text { Confirmation of } \\
\text { the transportation } \\
\text { agreement }\end{array}$ & $\begin{array}{l}\text { Procurement } \\
\text { management } \\
\text { agent }\end{array}$ \\
\hline
\end{tabular}

